\title{
Administrators' Perceptions of Motives to Offer Online Academic Degree Programs in Universities
}

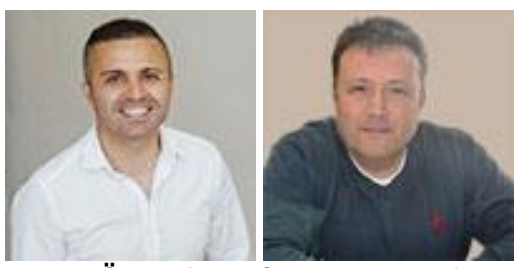

Hakan Özcan ${ }^{1}$ and Soner Yıldırım²

${ }^{1}$ Amasya University, ${ }^{2}$ Middle East Technical University

\begin{abstract}
Although the number of online academic degree programs offered by universities in Turkey has become increasingly significant in recent years, the current lack of understanding of administrators' motives that contribute to initiating these programs suggests there is much to be learned in this field. This study aimed to investigate administrators' perceptions of motives for offering online academic degree programs in universities in Turkey in terms of online associate degree programs, online master's degree programs, online bachelor's degree completion programs, and online bachelor's degree programs. A qualitative research method was employed for this study. Semi-structured interviews were conducted with 16 administrators from different universities' distance education centers in Turkey and thematic analysis was applied to the data. The research found that administrators' motives for offering online academic degree programs mainly involve in answering to the high demand of prospective students. Six major themes were identified with regard to influencing factors for administrators' motives: demands for programs, mission to support education, readiness of infrastructure, teaching staff as well as applicability of content, overcoming the shortage of classroom space and teachers, obtaining revenue, and gaining prestige.
\end{abstract}

Keywords: motives, distance education, online academic degree programs, administrators

\section{Introduction}

We are living in a world where technology develops day by day and plays an important role in our lives. As technology is rapidly advancing in today's world, it unavoidably becomes a part of our education (Çakır \& Yildirim, 2006). Accordingly, the technology of education is changing demographics and 
human's expectations for the learning environment and forcing change in higher education (Casares, Dickson, Hannigan, Hinton, \& Phelps, 2012). A report underlines: "People expect to be able to work, learn, and study whenever and wherever they want. This highly-ranked trend continues to permeate all aspects of daily life" (Johnson, Smith, Willis, Levine, \& Haywood, 2011, p. 3).

As technological improvements create new opportunities, distance education programs have become increasingly popular in the world. Jarvis (2007) reported that technology-enabled universities develop learning opportunities to attract more students and to cooperate across the world. Simonson, Smaldino, and Zvacek (2015) reported that The United Kingdom Open University was established in 1969 with the first students enrolled in January 1971. Simonson et al. (2015) report several examples that indicate the demand for distance learning opportunities. For example, Anadolu University, established in 1982 in Turkey, reaches more than 500,000 students; The Open University of Hong Kong, founded in 1989, so far has had over 100,000 students; China established a National Distance Higher Education program in the late 1970 s to early 1980 s, which offered more than 30,000 TV-based courses and hired approximately 25,000 faculty staff; and Spain's Universidad Nacional de Education a Distance has enrolled about 130,000 students (Simonson et al., 2015, pp. 13-15). Moreover, the advent of the Internet technologies has played an accelerating role in distance education practices. A report issued in November 2013 indicated that by the 2012 Fall semester, the number of students enrolled in distance education courses of degree-granting postsecondary institutions (higher education institutions) in the United States reached about 5.4 million, of whom $83 \%$ were undergraduate and $17 \%$ were postbaccalaureate students (Snyder \& Dillow, 2015). A more recent report by Allen and Seaman (2015) indicated almost the same results in terms of the registered students. According to The Distance Education Accrediting Commission (DEAC; 2017) there are currently 85 accredited distance education institutions in the United States that offer a variety of degree programs and some non-degree courses or programs. Thus, all of these numbers clearly demonstrate how distance education practices have had a global acceptance and popularity in the world.

\section{Increase in Online Academic Degree Programs in Turkey}

After the 1900s, as Internet-based distance education became an interest in Turkey, higher education institutions started to implement new opportunities for individuals. Universities throughout the country began to establish distance education institutions and centers to offer distance education programs. Between the years 1999-2002, a National Informatics Committee was established by the Higher Education Council (HEC) of Turkey to assure and accredit courses and programs of distance education institutions and support distance education in the country (Varol, 2010). In 2001, Anadolu University started the first completely online associate degree program in Turkey (Latchem, Özkul, Aydin, \& Mutlu, 2006). In 2002, there were more than 40 academic degree programs offered via distance education institutions associated with various universities in Turkey (Varol, 2002, pp. 12521254). Latchem et al. (2009) reported that Ankara University, one of the pioneers in distance education, founded the Distance Education Center (ANKUZEM) in 2002, and after a year, it started to offer distance education programs, and enrolled 1,190 students ( 940 undergraduate and 250 certificate). Latchem et al. (2009) further exemplified the other two pioneer universities offering distance education programs. The first one is Sakarya University, which has the Distance Learning Research and Development Center founded in 2005. The second example is Ahmet Yesevi University, which established the Internet-based Distance Education Department (TÜRTEP) in 2001.

In Turkey, due to the increasing trust in distance education using the Internet technologies, universities are turning to distance education implementations (Engin, 2013). As more universities started to 
implement distance education in their programs, universities' distance education applications in Turkey have increased in number accordingly. Today, many universities in Turkey offer distance education programs, ranging from master's degree, associate degree, bachelor's degree, bachelor's degree completion and certificate by providing on-campus or a combination of on-campus an off-campus education. According to the HEC reports there were about 75,000 students enrolled in the distance education programs in the 2015-2016 academic year (Higher Education Counsel [HEC], 2016). In 2016, according to the national Center for Student Selection and Assignment (CSSA), except for the traditional open education programs of Anadolu University, there were 35 universities actively offering 118 online academic degree programs (Center for Student Selection and Assignment [CSSA], 2016).

\section{Institutional Motives for Online Academic Degree Programs}

As universities increasingly implement distance education, it becomes essential to recognize the motives of institutions in planning a strategy for implementation of distance education, in order to better understand underlying dynamics of the increase in online programs in universities. According to earlier studies, institutional motives for offering distance education had the following factors: utilizing flexibility of the working environment (Betts, 1998; Dooley \& Murphrey, 2000; McKenzie, Mims, Bennett, \& Waugh, 2000; Rockwell, Schauer, Fritz \& Marx, 1999), improving the quality of education (Dooley \& Murphrey, 2000), contributing job satisfaction among faculty (Bonk, 2001; Dooley \& Murphrey, 2000; Harris \& Krousgill, 2008; Rockwell et al., 1999), supporting intellectual challenges and personal motivation to use technology (Betts, 1998; Panda \& Mishra, 2007), providing support for education (Dooley \& Murphrey, 2000; McKenzie et al., 2000), increasing access to the courses and enabling more students to attend education (Betts, 1998; Bonk, 2001; Dooley and Murphrey, 2000; Harris \& Krousgill, 2008), monetary support and earning additional income (Betts, 1998; Bonk, 2001; Schifter, 2002), and cost effectiveness (Betts, 1998). Although earlier studies indicated a link between institutional motives for participating in distance education and initiating distance education programs, currently there is no available information specifically about administrators' motives to offer online academic degree programs via distance education. In fact, the earlier studies have had a tendency to identify a limited view of institutional motivational factors with regard to distance education in the abstract, but not directly online academic degree programs.

\section{Purpose of the Study}

The purpose of the study is to explore administrator perceptions of motives for offering online academic degree programs in Turkish universities to better understand the dynamics of the increase in online academic degree programs from the administrators' point of view. In other words, the study aims to investigate motives for offering online associate degree programs, online master's degree programs, online bachelor's degree completion programs, and online bachelor's degree programs. In the end, it aims to identify all related motives in-depth, which will assist policy-makers and program leaders in determining the appropriate policies in planning distance education strategies of universities. This study was guided by the following four research questions:

1. What are the administrators' perception of motives to offer online associate degree programs?

2. What are the administrators' perception of motives to offer online master's degree programs?

3. What are the administrators' perception of motives to offer online bachelor's degree completion programs? 
4. What are the administrators' perception of motives to offer online bachelor's degree programs?

\section{Method}

\section{Sample and Population}

There were 47 university distance education centers in Turkey accredited by the HEC. Of these, 16 administrators (34\%) participated in the study as shown in Table 1. Initially convenience sampling was used in the study to recruit participants from the population, then further participants who could provide useful information were selected using purposeful sampling.

Table 1

Demographics of the Participants, Communication Types, Interview Durations, Locations, and Record Types

\begin{tabular}{|c|c|c|c|c|c|}
\hline$\#$ & Gender & $\begin{array}{l}\text { Academic title / } \\
\text { Position }\end{array}$ & $\begin{array}{l}\text { Experience } \\
\text { (Years) }\end{array}$ & Communication type & $\begin{array}{c}\text { Interview duration } \\
\text { (Minutes) }\end{array}$ \\
\hline 1 & Female & $\begin{array}{c}\text { Prof. Dr. / } \\
\text { Director }\end{array}$ & 2 & Face-to-face & 37 \\
\hline 2 & Male & $\begin{array}{l}\text { Assoc. Prof. Dr. } \\
\text { / Director }\end{array}$ & 2 & Face-to-face & 28 \\
\hline 3 & Male & $\begin{array}{l}\text { Assoc. Prof. Dr. } \\
\text { / Assist. Director }\end{array}$ & 3 & Face-to-face & 37 \\
\hline 4 & Male & $\begin{array}{l}\text { Research Assist. } \\
\text { / Assist. Director }\end{array}$ & 8 & Phone call & 38 \\
\hline 5 & Male & $\begin{array}{l}\text { Assoc. Prof. Dr. } \\
\text { / Director }\end{array}$ & 2 & Phone call & 26 \\
\hline 6 & Male & $\begin{array}{l}\text { Instructor / } \\
\text { Coordinator }\end{array}$ & 4 & Phone call & 25 \\
\hline 7 & Male & $\begin{array}{l}\text { Research Assist. } \\
\text { / Assist. Director }\end{array}$ & 11 & Phone call & 35 \\
\hline 8 & Male & $\begin{array}{l}\text { Assist. Prof. Dr. / } \\
\text { Director }\end{array}$ & 3 & Video call & 73 \\
\hline 9 & Male & $\begin{array}{l}\text { Assist. Prof. Dr. } \\
\text { / Director }\end{array}$ & 4 & Video call & 66 \\
\hline 10 & Male & $\begin{array}{l}\text { Assist. Prof. Dr. } \\
\text { / Assist. Director }\end{array}$ & 2 & Video call & 47 \\
\hline 11 & Male & $\begin{array}{l}\text { Assist. Prof. Dr. } \\
\text { / Assist. Director }\end{array}$ & 2 & Video call & 27 \\
\hline 12 & Male & $\begin{array}{l}\text { Assist. Prof. Dr. } \\
\text { / Assist. Director }\end{array}$ & 2 & Video call & 49 \\
\hline
\end{tabular}




\begin{tabular}{cccccc}
\hline 13 & Male & $\begin{array}{c}\text { Assist. Prof. Dr. } \\
\text { / Director }\end{array}$ & 5 & Video call & 44 \\
\hline 14 & Male & $\begin{array}{c}\text { Assoc. Prof. Dr. } \\
\text { / Director }\end{array}$ & 4 & Video call & 31 \\
\hline 15 & Male & $\begin{array}{c}\text { Prof. Dr. / } \\
\text { Director }\end{array}$ & 4 & Video call & 32 \\
\hline 16 & Female & $\begin{array}{c}\text { Assist. Prof. Dr. / } \\
\text { Assist. Director }\end{array}$ & 3 & Video call & 39 \\
\hline & Mean & & 3.8 & & 39.6 \\
\hline
\end{tabular}

The sampling strategy included the combination of maximum variation, convenience, and purposeful sampling method by reaching readily available participants, which instead of seeking representativeness through similar types of online academic programs, it was sought by including a broad range of participants, to have maximum heterogeneity according to types of online academic programs.

\section{Research Model}

The qualitative research method was employed for this study. Semi-structured interviews were conducted with 16 administrators from different universities' distance education centers in Turkey and thematic analysis was applied to the data.

\section{Data Collection Tools, Reliability, and Validity Studies}

In this study, a semi-structured interview schedule was used to explore the administrators' perception of motives to offer online academic degree programs. It was aimed to let the interviewee state perceptions, opinions, and characteristics with regard to motives freely and in detail. Checking coding consistency and revising codes was made before applying the codes to all the data. To avoid bias and multiple interpretations of data, a peer evaluation was conducted by a subject expert, and a clarification of responses was assured by contacting interviewees a second time. After the pilot study was conducted, the researcher had a set of preliminary codes, but as the study continued, the codes were enhanced and increased in number resulting in the development of themes and concepts. Finally, all the findings were merged and revised with the suggestions of four subject field experts again. All of the interviews were completed during the year 2014.

The participants of this study were limited to the administrators of universities, who were readily available, who voluntarily agreed to participate, and were not necessarily representative of all universities. The validity of this study is limited to the reliability of the data, which accordingly relies on the instrument and the participants' honesty in their responses to the interview questions. Therefore, the study assumed that the participants would explain the institutional motivational factors that influence offering the online academic degree programs, and that the participants responded to the interview questions honestly and accurately. 


\section{Findings and Interpretation}

Qualitative analysis methods were employed in order to extract themes from open-ended questions. Thematic analysis was applied to examine themes within the data. First, the researcher transcribed each recording and the related notes, then read through the transcribed data, dividing into parts (segments, concepts) and then assigning codes for each relevant text by searching and reading the whole data. The codes were then further reduced and merged into extracted themes and concepts by grouping the related codes.

\section{Administrators' Conceptions of Motives in Offering Online Associate Degree Programs}

To understand the conceptions of motives for offering online associate degree programs, participants were asked the interview question; "What are your motives to offer online associate degree programs?" An in-depth analysis of transcribed interviews identified six themes; "Demands" (13 participants), "Readiness" (9 participants), "Revenue" (6 participants), "Mission" (5 participants), "Prestige" (3 participants), and "Needs" (2 participants) as the characteristics of administrators' conceptions of motives for offering online associate degree programs. Twelve key concepts were extracted through the categorization of the responses. The themes and concepts are listed in Table 2 with frequencies.

Table 2

Administrators' Conceptions and Frequencies about the Motives of Offering Online Associate Degree Programs Characteristics

\begin{tabular}{|c|c|c|c|}
\hline Themes & $\mathrm{F}$ & Concepts & $\mathrm{F}$ \\
\hline \multirow[t]{3}{*}{ Demands } & \multirow[t]{3}{*}{13} & Meeting the demands of prospective students & 8 \\
\hline & & Meeting the interest of teaching staff & 6 \\
\hline & & Meeting the demands of the HEC & 1 \\
\hline \multirow[t]{3}{*}{ Readiness } & \multirow[t]{3}{*}{9} & Utilizing the readiness of teaching staff & 5 \\
\hline & & Utilizing the applicability of content & 3 \\
\hline & & Utilizing the readiness of infrastructure & 3 \\
\hline \multirow[t]{2}{*}{ Mission } & \multirow[t]{2}{*}{6} & Support for education & 5 \\
\hline & & Meeting the demands of region & 2 \\
\hline \multirow[t]{2}{*}{ Revenue } & \multirow[t]{2}{*}{5} & Contribution to the financial satisfaction of teaching staff & 4 \\
\hline & & Contribution to budget & 3 \\
\hline Prestige & 3 & Gaining prestige & 3 \\
\hline Needs & 2 & Overcoming the shortage of classrooms and teachers & 2 \\
\hline
\end{tabular}

*Note. Some participants have more than one concept and represented more than one theme, so the sum of frequencies is greater than the number of participants. There was a total of 14 respondents to the question "What are your motives to offer online associate degree programs?"

According to the interviewees' responses, "Demands" (13 participants), "Readiness" (9 participants), "Revenue" (6 participants), "Mission" (5 participants), "Prestige" (3 participants), and "Needs" (2 participants) were regarded as the characteristics of administrators' conceptions of motives for offering 
online associate degree programs. Administrators thought that online associate degree programs were offered to meet the prospective demands of students, the interest of teaching staff and the demands of the HEC; to utilize the readiness of teaching staff, the applicability of content and the readiness of infrastructure; to support education and to meet the demands of the region; to contribute to the financial satisfaction of teaching staff and to budget of the university; to gain prestige; and to overcome the shortage of classrooms and teachers.

\section{Administrators' Conceptions of Motives in Offering Online Master's Degree Programs}

Participants were asked the interview question; "What are your motives to offer online master's degree programs?" An in-depth analysis of transcribed interviews identified six themes; "Demands" (14 participants), "Revenue" (8 participants), "Readiness" (7 participants), "Mission" (6 participants), "Prestige" (5 participants), "Needs" (3 participants) as the characteristics of their conceptions of motives for offering online master's degree programs. Thirteen key concepts were extracted through the categorization of the responses. The themes and concepts are listed in Table 3 with frequencies.

Table 3

Administrators' Conceptions and Frequencies about the Motives of Offering Online Master's Degree Programs Characteristics

\begin{tabular}{|c|c|c|c|}
\hline Themes & $\mathrm{F}$ & Concepts & $\mathrm{F}$ \\
\hline \multirow[t]{4}{*}{ Demands } & \multirow[t]{4}{*}{14} & Meeting the demands of prospective students & 10 \\
\hline & & Meeting the interest of teaching staff & 8 \\
\hline & & Meeting the demands of institutions & 2 \\
\hline & & Meeting the demands of university & 1 \\
\hline \multirow[t]{2}{*}{ Revenue } & \multirow[t]{2}{*}{8} & Contribution to budget & 7 \\
\hline & & Contribution to the financial satisfaction of teaching staff & 3 \\
\hline \multirow[t]{2}{*}{ Mission } & \multirow[t]{2}{*}{7} & Support for education & 6 \\
\hline & & Improving the quality of education & 3 \\
\hline \multirow[t]{3}{*}{ Readiness } & \multirow[t]{3}{*}{6} & Utilizing the readiness of infrastructure & 3 \\
\hline & & Utilizing the readiness of teaching staff & 3 \\
\hline & & Utilizing the applicability of content & 3 \\
\hline Prestige & 5 & Gaining prestige & 5 \\
\hline Needs & 3 & Overcoming the shortage of classrooms & 3 \\
\hline
\end{tabular}

*Note. Some participants have more than one concept and represented more than one theme, so the sum of frequencies is greater than the number of participants. There was a total of 15 respondents to the question "What are your motives to offer online master's degree programs?" 
Based on the interviewees' responses, "Demands" (14 participants), "Revenue" (8 participants), "Readiness" (7 participants), "Mission" (6 participants), "Prestige" (5 participants), "Needs" (3 participants) were underlined as the characteristics of administrators' conceptions of motives for offering online master's degree programs. Administrators thought that online master's degree programs were offered to meet the demands of prospective students, the interest of teaching staff, the demands of institutions, and the demands of university; to contribute to the budget and financial satisfaction of teaching staff; to support education; to improve the quality of education; to utilize the readiness of infrastructure, teaching staff, and the applicability of content; to gain prestige; and to overcome the shortage of classrooms.

\section{Administrators' Conceptions of Motives in Offering Online Bachelor's Degree Completion Programs}

Participants were asked the question; "What are your motives to offer online bachelor's degree completion programs?" After the analysis of transcribed interviews, six themes were identified; "Demands" (7 participants), "Revenue" (5 participants), and "Mission" (3 participants) as the characteristics of their conceptions of motives for offering online bachelor's degree completion programs. Six key concepts were extracted through the categorization of the responses. The themes and concepts are listed in Table 4 with frequencies.

\section{Table 4}

Administrators' Conceptions and Frequencies about the Motives of Offering Online Bachelor's Degree Completion Programs Characteristics

\begin{tabular}{|c|c|c|c|}
\hline Themes & $\mathrm{F}$ & Concepts & $\mathrm{F}$ \\
\hline \multirow[t]{2}{*}{ Demands } & 7 & Meeting the demands of prospective students & 5 \\
\hline & & Meeting the demands of university & 4 \\
\hline \multirow[t]{2}{*}{ Revenue } & 5 & Contribution to budget & 3 \\
\hline & & Contribution to the financial satisfaction of teaching staff & 2 \\
\hline \multirow[t]{2}{*}{ Mission } & 3 & Support for education & 2 \\
\hline & & Meeting the demands of region & 1 \\
\hline
\end{tabular}

*Note. Some participants have more than one concept and represented more than one theme, so the sum of frequencies is greater than the number of respondents. There was a total of 10 respondents to the question "What are your motives to offer online bachelor's degree completion programs?

According to interviewees' responses, "Demands" (7 participants), "Revenue" (5 participants), and "Mission" (3 participants) were underlined as the characteristics of their conceptions of motives for offering online bachelor's degree completion programs. Administrators believed that online bachelor's degree completion programs were offered to meet the demands of prospective students and universities, to contribute to the budget and financial satisfaction of teaching staff, to support education, and to meet the demands of the region. 


\section{Administrators' Conceptions of Motives in Offering Online Bachelor's Degree Programs}

In order to determine conceptions of motives for offering online bachelor's degree programs, participants were asked the question, "What are your motives to offer online bachelor's degree programs?" After a detailed analysis of transcribed interviews, five themes were identified; "Demands" (3 participants), "Needs" (3 participants), "Readiness" (2 participants), "Revenue" (1 participant), and "Prestige" (1 participant) as the characteristics of their conceptions of motives for offering online bachelor's degree programs. Five key concepts were extracted through the categorization of the responses. There was a decrease in the number of participants responding to this question because of the fact that only some of the participants were offering or planning to offer online bachelor's degree programs. The themes and concepts are listed in Table 5 with frequencies.

Table 5

Administrators' Conceptions and Frequencies about the Motives of Offering Online Bachelor's Degree Programs Characteristics

\begin{tabular}{lclc}
\hline Themes & F & & Concepts \\
\hline Demands & 3 & Meeting the demands of prospective students & 3 \\
\hline Needs & 3 & Overcoming the shortage of classrooms and teachers & 3 \\
\hline Readiness & 2 & Utilizing the applicability of content & 2 \\
\hline Revenue & 1 & Contribution to the financial satisfaction of teaching staff & 1 \\
\hline Prestige & 1 & Gaining prestige & 1
\end{tabular}

*Note. Some participants have more than one concept and represented more than one theme, so the sum of frequencies is greater than the number of respondents. There was a total of 6 respondents to the question "What are your motives to offer online bachelor's degree programs?"

Based on the interviewees' responses, "Demands" (3 participants), "Needs" (3 participants), "Readiness" (2 participants), "Revenue" (1 participant), and "Prestige" (1 participant) were underlined as the characteristics of administrators' conceptions of motives for offering online bachelor's degree programs. Administrators thought that online bachelor's degree programs were offered to meet the demands of prospective students, to overcome the shortage of classrooms and teachers, to utilize the applicability of content to distance education, to contribute to the financial satisfaction of teaching staff, and to gain prestige. 


\section{Conclusions and Discussion}

As a result of this study, the following conclusions with respect to administrators' conceptions of motives in offering online academic degree programs have been derived:

\section{Administrators' Perception of Motives to Offer Online Associate Degree Programs}

- The main factors that determine the motives of the administrators to offer online associate degree programs are willingness of teaching staff to participate in online teaching and prospective students' demands, mainly because of receiving the same diploma as traditional on-campus students. Universities tend to accommodate custom online programs requested from prospective students via email, phone, or web. In addition, the willingness of instructors to form these programs strongly impacts universities' decision to initiate online associate degree programs.

- Having readily available infrastructure and well-experienced teaching staff, who are dedicated and willing to serve students in a distance education setting, plays an important role in offering online associate degree programs. For launching online associate degree programs, universities need learning management systems, content, servers, technical support, as well as wellexperienced teaching staff.

- Administrators' motives are additionally based on the value of the institutional mission, which supports offering these programs in order to provide a wider opportunity for higher education in society. For example, universities that are located in certain areas are offering online associate degree programs depending on the needs of the region such as Tourism and Hotel Management.

- Income gains effect administrators' motives to some extent. These programs contribute to the budget and give teaching staff financial saturation. Teachers need to supplement their income. With the help of these programs they initiate ways that teachers can expand their income possibilities.

- Lastly, with the help of online associate degree programs, universities also, to a lesser extent, try to overcome the shortage of classroom space.

\section{Administrators' Perception of Motives to Offer Online Master's Degree Programs}

- The root causes that mainly shape administrators' motive to offer online master's degree programs are prospective students' demands for the programs and the level of interest of teaching staff. Universities are profoundly inspired by the top programs discovered through both prospective students' requests and other universities' implementations, thereby preferably attracting an increasing number of students. Additionally, it is regarded, rather, as an academic study opportunity for teaching staff. Accordingly, teaching staff's motivation and enthusiasm for academic study initiate administrators' motives for offering these programs.

- Another bottom line factor that shapes motives for offering online master's degree programs is the profitability. The factors; prospective students' demands and profitability of these programs interrelatedly effect administrators' motives to offer online master's degree programs. In other words, distance education centers prefer to offer online master's degree programs that already attract interest and, consequently, support the budget. For example, offering online business 
degree programs meet increased prospective students' demands, and generate more revenue for universities.

- Moreover, institutional mission has an effect on administrators' motives to offer online master's degree programs. Universities' mission statements include an emphasis on improving the quality of education and spreading it to the great masses. These strategic intents to provide people lifelong learning and advance the quality of education in the country, drive program leaders to offer online master's degree programs.

- Administrators' motives for offering online master's degree programs additionally depend on readily available infrastructure, ease of content adaptability, as well as availability of experienced teaching staff.

- Lastly, administrators' motives for offering online master's degree programs are also driven by institutional ambitions to some extent, how these programs improve popularity and prestige among national universities in an increasingly competitive environment, and to a lesser extent, how they lessen the burden of classroom space.

\section{Administrators' Perception of Motives to Offer Online Bachelor's Degree Completion Programs}

- Primary motives of administrators to offer online bachelor's degree completion programs are under the influence of requests that come from two sources: Prospective students, with an expectation of improved personal rights for meeting employment requirements in order to be promoted to a higher level; and the university or the department.

- Factors for economic contribution to the budget, as well as improvement in teaching staff's financial satisfaction by providing an extra income, contribute to the institutional motives to some extent for offering online bachelor's degree completion programs.

- Additionally, universities try to create equal opportunities for students with disabilities or work commitments. Institutional motives to contribute towards creating equal opportunities for those who are unable to attend courses drive universities to offer online bachelor's degree completion programs.

\section{Administrators' Perception of Motives to Offer Online Bachelor's Degree Programs}

- Administrators' motives to offer online bachelor's degree programs mainly include answering to the high demand of prospective students and building an economic learning environment by reducing face-to-face teaching in classrooms so as to reduce the burden of classroom space and teaching staff.

- Other decisive factors, but to a lesser extent, that influence motives to offer online bachelor's degree programs are applicability of content, and adaptation to distance education. In other words, if core contents are appropriate for distance education, program leaders are more inclined to include them in the distance education centers catalogs of universities, because they want to spend less time to prepare for the sessions. 
Although earlier studies are not directly related to online academic degree programs, similar findings in some of the different studies exist in the general framework of institutional incentives for distance education, which can be regarded as a basis for comparing the findings of this qualitative study. This study indicated that the common motive of administrators to offer online academic programs are shaped in accordance with meeting increased prospective students' demands in online programs, which also supported by a limited number of earlier studies in terms of faculty's intention to offer distance education for enabling more students to attend education (Betts, 1998; Bonk, 2001; Dooley \& Murphrey, 2000). Additionally, Harris and Krousgill (2008) reported an overview of distance education with regard to the new directions, which also underline that due to the nature of distance education each institution wants to provide learning opportunities. With this opportunity, it is aimed to reach more students especially for those who cannot continue traditional education (Harris \& Krousgill, 2008). Another common administrator motive for offering online academic programs is support for financial satisfaction of teaching staff to some extent. This finding of the study is also in line with the previous literature in terms of faculty's incentive related to earning additional income through distance education (Betts, 1998; Bonk, 2001). Moreover, Rockwell et al. (1999) reported that the major motive to deliver distance education is intrinsic in that rewards play an important role, as well as job satisfaction, in order to motivate faculty to offer distance education. Similarly, Engin (2013) underlined that in order to have more innovative applications in distance education, there is need of providing professional incentives. Additionally, Betts (1998) revealed a number of factors that initiate faculty's motives to start involving in distance education. Betts summarized that earning additional income, tenure, promotion, and job satisfaction motivate faculty to develop distance education opportunities (Betts, 1998). Similarly, this study also indicated that one of the motives of administrators for developing distance education programs is its contribution to budget, and contribution to the financial satisfaction of teaching staff. With regard to online associate degree programs, online master's degree programs, and online bachelor's degree completion programs, the study showed that administrators' motives to offer these programs involve in developing and advancing the quality of education in the country, which is consistent with previous studies in respect of providing support for education (McKenzie et al., 2000). Additionally, Dooley and Murphrey (2000) reported that using new technologies to enhance the quality of education, opportunity for collaborations with other institutions, facilitating access for students, administrative assistance, and getting support for educational design were motivational factors to make them begin or continue distance education. As a result, the research findings are parallel to the literature under the headings of job satisfaction, additional income, and support for education. This study additionally revealed that demands of prospective students, gaining prestige, and need of classroom space or teaching staff are also contributing motivational factors with regard to distance education. Since the earlier studies were focused on only distance education in the abstract, but not online academic degree programs, this study more specifically explored administrator motivation for offering online associate degree programs, online master's degree programs, online bachelor's degree completion programs, and online bachelor's degree programs in universities. As for the newly discovered factors in the study, they are likely due to the growth in prospective students in education in the country, current competition for student retention, which is fostered by the pursuit of prestige among universities, and the increased need for classroom space and the potential need for teaching staff.

\section{Suggestions}

It is obvious that online academic degree programs at Turkish universities are mainly shaped by prospective students' demands through the diffusion of popular online programs, rather than in 
accordance with academic expectations. Thus, the policies should be reviewed and audited to ensure that online academic degree programs clearly lay out academic expectations for enrolled students. Although universities offer some mission-related online courses, they are often considered as unprofitable or not practical. In fact, universities find it is not cost-effective to set up new infrastructure for distance education or, for the same reason, they do not want to develop online academic degree programs, which attract less students. Bates (2000) suggests that institutions can share the costs and increase benefits through collaboration. Decision makers can establish mutual organizational structure and enhance the cooperation between universities in such a way that the cost of producing content can be reduced. Bates also underlines the importance of developing a dedicated policy for administrative and academic procedures. Policy makers and program leaders should therefore structure the procedures for initiating online academic degree programs in such a way that expectations are definitely delineated in accordance with the country's educational goals. As previously mentioned, there are no other studies about administrators' motives for offering online academic degree programs in universities. In fact, the earlier studies have a tendency to identify a limited view of institutional motivational factors with regard to distance education in the abstract, but not directly online academic degree programs. Therefore, this study can be regarded as a significant contribution to the field, as it provides researchers with detailed tables of motives in offering online academic degree programs, which may have implications for use in future studies, can assist policy-makers and program leaders in determining the appropriate policies in planning distance education strategies. Further studies can be conducted to reveal distorting factors influential on offering online academic degree programs, which may provide a holistic perspective to fully understand the research problem.

\section{Acknowledgements}

This study was adapted from a master's thesis submitted to Middle East Technical University, and a part of it was presented at the International Computer and Instructional Technologies Symposium held May 20-22, 2015 in Afyonkarahisar, Turkey. 


\section{References}

Allen, I. E., \& Seaman, J. (2015). Grade level: Tracking online education in the United States. Babson Survey Research Group. Retrieved from http://www.onlinelearningsurvey.com/reports/gradelevel.pdf

Bates, A.W. (2000). Managing technological change: Strategies for college and university leaders. San Francisco: Jossey-Bass

Betts, K.S. (1998). An institutional overview: Factors influencing faculty participation in distance education in postsecondary education in the United States: An institutional study. Online Journal of Distance Learning Administration, 1(3). Retrieved from http://www.westga.edu/ distance/betts13.html

Bonk, C. (2001). Online teaching in an online world. Bloomington, IN: CourseShare.com. Retrieved from http://publicationshare.worldisopen.com/docs/faculty survey report.pdf

Çakır, R. \& Yildirim S. (2006). Are computer teachers trained for the teaching profession? An assessment of a computer teacher training program. Education and Science, 31(142), 35-44.

Casares, J., Dickson, D. A., Hannigan, T., Hinton, J., \& Phelps, A. (2012). The future of teaching and learning in higher education. Retrieved from https://www.rit.edu/academicaffairs/sites/rit.edu.academicaffairs/files/docs/future of teac hing_and_learning_reportv13.pdf

Center for Student Selection and Assignment. (2016). Guidebook for higher education programs and quotas. Retrieved from http://dokuman.osym.gov.tr/pdfdokuman/2016/LYS/ TERCIH/OSYSKONTKILAVUZU01082016.pdf

Distance Education Accrediting Commission. (2017). Directory of accredited institutions. Retrieved from https://www.deac.org/Student-Center/Directory-Of-Accredited-Institutions.aspx

Dooley, K. E., \& Murphrey, T. P. (2000). How the perspectives of administrators, faculty and support units impact the rate of distance education adoption. Online Journal of Distance Learning Administration, 3(4). Retrieved from https://www.westga.edu/ distance/ojdla/winter34/dooley34.html

Engin, M. (2013). Investzgation of creation, application and management processes of technologybased distance education systems at universities (Unpublished doctoral dissertation, Ankara University, Turkey).

Harris, D. A., \& Krousgrill, C. (2008). Distance education: New technologies and new directions. Proceedings of the IEEE, 96(6), 917-930. doi: 10.1109/JPROC.2008.921612

Higher Education Counsel. (2016). Öğrenci sayıları özet tablosu [Summary table of number of students; online document]. Retrieved from https://istatistik.yok.gov.tr/yuksekogretimIstatistikleri/2016/2016 T1.pdf 
Jarvis, P. (2007). Globalization, Lifelong learning and the learning society: Sociological perspectives (Vol. 2). London: Routledge.

Johnson, L., Smith, R., Willis, H., Levine, A., \& Haywood, K. (2011). The 2011 Horizon Report. Austin, Texas: The New Media Consortium. Retrieved from https://www.nmc.org/system/files/pubs/1316814265/2011-Horizon-Report(2).pdf

Latchem, C., Özkul, A.E., Aydin, C.H., \& Mutlu, M.E. (2006) The open education system, Anadolu University, Turkey: e-transformation in a mega-university. Open Learning, 21(3), 221-235. Retrieved from http://ocw.metu.edu.tr/file.php/118/Week10/Lathchem open-learning-AOF2006.pdf

Latchem, C., Simsek, N., Cakir, O., Torkul, O., Cedimoglu, I., \& Altunkopru, A. (2009). Are we there yet? A progress report from three Turkish university pioneers in distance education and elearning. The International Review of Research in Open and Distance Learning, 10(2). Retrieved from http://www.irrodl.org/index.php/irrodl/article/view/686/1220

McKenzie, B.K., Mims, N., Bennett, E.K., \& Waugh, M. (2000). Needs, concerns, and practices of online instructors. Online Journal of Distance Learning Administration, 3(3). Retrieved from http://www.westga.edu/ distance/ojdla/fall33/mckenzie33.html

Panda, S., \& Mishra, S. (2007). E-learning in a mega Open University: Faculty attitude, barriers and motivators. Educational Media International, 44(4), 323-338.

Rockwell, S.K., Schauer, J., Fritz, S.M., \& Marx, D.B. (1999). Incentives and obstacles influencing higher education faculty and administrators to teach via distance. Online Journal of Distance Learning Administration, 2(3). Retrieved from http://www.westga.edu/ حdistance/rockwell24.html

Schifter, C. (2002). Perception differences about participating in distance education. Online Journal of Distance Learning Administration, 5(1).

Simonson, M., Smaldino, S., \& Zvacek, S. (2015). Teaching and learning at a distance: Foundations of distance education (6th ed.) Charlotte, NC: Information Age.

Snyder, T. D., \& Dillow, S. A. (2015). Digest of education statistics, 2013. National Center for Education Statistics, Institute of Education Sciences, U.S. Department of Education. Washington, D.C. Retrieved from https://files.eric.ed.gov/fulltext/ED556349.pdf

Varol, A. (2002, September). YÖK enformatik milli komitesinnin misyonu [The Mission of the national ınformatics committee]. In Bilişim, Bildiriler Kitabı (pp. 245-251), Istanbul, Retrieved from http://www.asafvarol.com/makaleler/dorduncubolum33.pdf

Varol, A. (2010, April). Distance education studies of firat university. 1oth International Educational Technology Conference \& Exhibition, Proceeedings CD, Istanbul, Turkey. Retrieved from http://asafvarol.com/makaleler/ikincibolum15.pdf 
Athabasca

University

(c) (P) 